\title{
Period Formulas for Moment-Resisting Frame Buildings
}

\author{
By Rakesh K. Goel ${ }^{1}$ and Anil K. Chopra ${ }^{2}$
}

\begin{abstract}
Most seismic codes specify empirical formulas to estimate the fundamental vibration period of buildings. Evaluated first in this paper are the formulas specified in present U.S. codes using the available data on the fundamental period of buildings "measured" from their motions recorded during eight California earthquakes, starting with the 1971 San Fernando earthquake and ending with the 1994 Northridge earthquake. It is shown that, although the code formulas provide periods that are generally shorter than measured periods, these formulas can be improved to provide better correlation with the measured data. Subsequently, improved formulas for estimating the fundamental periods of reinforced concrete (RC) and steel moment-resisting frame buildings are developed by regression analysis of the measured period data. Also recommended are factors to limit the period calculated by a rational analysis, such as Rayleigh's method.
\end{abstract}

\section{INTRODUCTION}

The fundamental vibration period of a building appears in the equation specified in building codes to calculate the design base shear and lateral forces. Because this building property cannot be computed for a structure that is yet to be designed, building codes provide empirical formulas that depend on the building material [steel, reinforced concrete (RC), etc.], building type (frame, shear wall, etc.), and overall dimensions.

The period formulas in the 1997 Uniform Building Code (UBC) (UBC 1997) and the 1996 Structural Engineers Association of California (SEAOC) recommendations (SEAOC 1996) are derived from those developed in 1975 as part of the ATC3-06 project [Applied Technological Council (ATC) 1978] largely based on periods of buildings "measured" from their motions recorded during the 1971 San Fernando earthquake. However, motions of many more buildings recorded during recent earthquakes, including the 1989 Loma Prieta and 1994 Northridge earthquakes, are now available. These recorded motions provide an opportunity to expand greatly the existing database on the fundamental vibration periods of buildings. To this end, the natural vibration periods of 21 buildings have been measured by system identification methods applied to the motions of buildings recorded during the 1994 Northridge earthquake (Goel and Chopra 1997). These data have been combined with similar data from the motions of buildings recorded during the 1971 San Fernando, 1984 Morgan Hill, 1986 Mt. Lewis and Palm Spring, 1987 Whittier, 1989 Loma Prieta, 1990 Upland, and 1991 Sierra Madre earthquakes reported by several investigators [an exhaustive list of references is available in Goel and Chopra (1997)].

The objective of this paper is develop improved empirical formulas to estimate the fundamental vibration period of RC and steel moment-resisting frame (MRF) buildings for use in equivalent lateral force analysis specified in building codes. Presented first is the expanded database for measured values of fundamental periods of MRF buildings, against which the empirical formulas in present U.S. codes are evaluated. Subsequently, regression analysis of the measured data is used to develop improved formulas for estimating the fundamental periods of RC MRF buildings and of steel MRF buildings.

\footnotetext{
${ }^{1}$ Asst. Prof., Dept. of Civ. and Envir. Engrg., Syracuse Univ., Syracuse, NY, 13244-1190; currently at Dept. of Civ. and Envir. Engrg., Cal Poly State Univ., San Luis Obispo, CA 93407.

${ }^{2}$ Johnson Prof., Dept. of Civ. Engrg., Univ. of California, Berkeley, CA 94720 .
}

Finally, factors to limit the period calculated by a rational analysis, such as Rayleigh's method, are recommended.

\section{PERIOD DATABASE}

The data that are most useful but hard to come by are from structures shaken strongly but not deformed into the inelastic range. Such data are slow to accumulate because relatively few structures are installed with permanent accelerographs and earthquakes causing strong motions of these instrumented buildings are infrequent. Thus, it is very important to investigate comprehensively the recorded motions when they do become available, as during the 1994 Northridge earthquake. Unfortunately, this obviously important goal is not always accomplished, as indicated by the fact that the vibration properties of only a few of the buildings whose motions were recorded during post-1971 earthquakes have been determined.

Available data on the fundamental vibration period of buildings measured from their motions recorded during several $\mathrm{Cal}$ ifornia earthquakes have been collected (Goel and Chopra 1997). This database contains data for a total of 106 buildings, including 21 buildings that experienced peak ground acceleration, $\ddot{u}_{g 0} \geq 0.15 \mathrm{~g}$ during the 1994 Northridge earthquake. The remaining data comes from motions of buildings recorded during the 1971 San Fernando earthquake and subsequent earthquakes (Hart and Vasudevan 1975; ATC 1978; Bertero et al. 1988; Cole et al. 1992; Goel and Chopra 1997).

Shown in Tables 1 and 2 is the subset of this database pertaining to MRF buildings including 37 data points for $27 \mathrm{RC}$ MRF buildings and 53 data points for 42 steel MRF buildings; buildings subjected to $\ddot{u}_{g 0} \geq 0.15 \mathrm{~g}$ are identified with an asterisk. The " $\mathrm{C}$," " $\mathrm{U}$," and " $\mathrm{N}$ " denote buildings instrumented by the California Strong Motion Instrumentation Program (CSMIP), United States Geological Survey (USGS), and National Oceanic and Atmospheric Administration (NOAA); "ATC" denotes buildings included in the ATC3-06 report (ATC 1978). The number of data points exceeds the number of buildings because the period of some buildings was determined from their motions recorded during more than one earthquake or was reported by more than one investigator for the same earthquake.

\section{CODE FORMULAS}

The empirical formulas for the fundamental vibration period of MRF buildings specified in U.S. building codes-UBC-97 (UBC 1997), ATC3-06 (ATC 1978), SEAOC-96 (SEAOC 1996), and NEHRP-94 (NEHRP 1994) - are of the form

$$
T=C_{r} H^{3 / 4}
$$

where $H=$ height of the building in feet above the base; and the numerical coefficient $C_{t}=0.030$ and 0.035 for $\mathrm{RC}$ and 
TABLE 1. Perlod Data for RC MRF Buildings

\begin{tabular}{|c|c|c|c|c|c|c|c|}
\hline \multirow[b]{2}{*}{$\begin{array}{l}\text { No. } \\
\text { (1) }\end{array}$} & \multirow[b]{2}{*}{$\begin{array}{l}\text { Location } \\
\text { (2) }\end{array}$} & \multirow[b]{2}{*}{$\begin{array}{l}\text { ID number } \\
\text { (3) }\end{array}$} & \multirow[b]{2}{*}{$\begin{array}{l}\text { No. of stories } \\
\text { (4) }\end{array}$} & \multirow[b]{2}{*}{$\begin{array}{l}\text { Height (ft) } \\
\text { (5) }\end{array}$} & \multirow[b]{2}{*}{$\begin{array}{c}\text { Earthquake } \\
(6)\end{array}$} & \multicolumn{2}{|c|}{ Period $T$ (s) } \\
\hline & & & & & & $\begin{array}{l}\text { Longitudinal } \\
(7)\end{array}$ & $\begin{array}{c}\text { Transverse } \\
\text { (8) }\end{array}$ \\
\hline $\begin{array}{l}1 \\
2 \\
3 \\
4 \\
5 \\
6 \\
7 \\
8 \\
9 \\
10 \\
11 \\
12 \\
13^{*} \\
14^{*} \\
15^{*} \\
16^{*} \\
17^{*} \\
18^{*} \\
19^{*} \\
20^{*} \\
21^{*} \\
22^{*} \\
23^{*} \\
24 \\
25 \\
26 \\
27 \\
28 \\
29 \\
30 \\
31 \\
32 \\
33^{*} \\
34^{*} \\
35^{*} \\
36 \\
37^{*}\end{array}$ & $\begin{array}{l}\text { Emeryville } \\
\text { Los Angeles } \\
\text { Los Angeles } \\
\text { Los Angeles } \\
\text { Los Angeles } \\
\text { Los Angeles } \\
\text { Los Angeles } \\
\text { Los Angeles } \\
\text { Los Angeles } \\
\text { Los Angeles } \\
\text { Los Angeles } \\
\text { Los Angeles } \\
\text { Los Angeles } \\
\text { Los Angeles } \\
\text { Los Angeles } \\
\text { Los Angeles } \\
\text { Los Angeles } \\
\text { Los Angeles } \\
\text { Los Angeles } \\
\text { Los Angeles } \\
\text { Los Angeles } \\
\text { Los Angeles } \\
\text { North Hollywood } \\
\text { North Hollywood } \\
\text { Pomona } \\
\text { Pomona } \\
\text { San Bruno } \\
\text { San Bruno } \\
\text { San Jose } \\
\text { San Jose } \\
\text { San Jose } \\
\text { San Jose } \\
\text { Sherman Oaks } \\
\text { Sherman Oaks } \\
\text { Sherman Oaks } \\
\text { Van Nuys } \\
\text { Van Nuys }\end{array}$ & $\begin{array}{l}\text { NA } \\
\text { NA } \\
\text { NA } \\
\text { NA } \\
\text { ATC_112 } \\
\text { ATC_14 } \\
\text { ATC_2 } \\
\text { ATC_3 } \\
\text { ATC_5 } \\
\text { ATC_6 } \\
\text { ATC_7 } \\
\text { ATC_9 } \\
\text { C24236 } \\
\text { C24463 } \\
\text { C24463 } \\
\text { C24569 } \\
\text { C24579 } \\
\text { N220-2 } \\
\text { N220-2 } \\
\text { N220-2 } \\
\text { N446-8 } \\
\text { N446-8 } \\
\text { C24464 } \\
\text { C24464 } \\
\text { C23511 } \\
\text { C23511 } \\
\text { C58490 } \\
\text { C58490 } \\
\text { NA } \\
\text { C57355 } \\
\text { C57355 } \\
\text { C57355 } \\
\text { ATC_4 } \\
\text { C24322 } \\
\text { C24322 } \\
\text { ATC_1 } \\
\text { C24386 }\end{array}$ & $\begin{array}{r}30 \\
9 \\
14 \\
13 \\
10 \\
7 \\
7 \\
12 \\
19 \\
11 \\
22 \\
16 \\
14 \\
5 \\
5 \\
15 \\
9 \\
20 \\
20 \\
20 \\
22 \\
22 \\
20 \\
20 \\
2 \\
2 \\
6 \\
6 \\
5 \\
10 \\
10 \\
10 \\
13 \\
13 \\
13 \\
7 \\
7\end{array}$ & $\begin{array}{r}300.0 \\
120.0 \\
160.0 \\
166.0 \\
137.5 \\
61.0 \\
68.0 \\
159.0 \\
196.8 \\
124.0 \\
204.3 \\
152.0 \\
148.8 \\
119.0 \\
119.0 \\
274.0 \\
141.0 \\
196.8 \\
196.8 \\
196.8 \\
204.3 \\
204.3 \\
169.0 \\
169.0 \\
30.0 \\
30.0 \\
78.0 \\
78.0 \\
65.0 \\
124.0 \\
124.0 \\
124.0 \\
124.0 \\
184.5 \\
184.5 \\
65.7 \\
65.7\end{array}$ & $\begin{array}{l}\text { Loma Prieta } \\
\text { San Fernando } \\
\text { San Fernando } \\
\text { San Fernando } \\
\text { San Fernando } \\
\text { San Fernando } \\
\text { San Fernando } \\
\text { San Fernando } \\
\text { San Fernando } \\
\text { San Fernando } \\
\text { San Fernando } \\
\text { San Fernando } \\
\text { Northridge } \\
\text { Northridge } \\
\text { Whittier } \\
\text { Northridge } \\
\text { Northridge } \\
\text { San Fernando } \\
\text { San Fernando } \\
\text { San Fernando } \\
\text { San Fernando } \\
\text { San Fernando } \\
\text { Northridge } \\
\text { Whittier } \\
\text { Upland } \\
\text { Whittier } \\
\text { Loma Prieta } \\
\text { Loma Prieta } \\
\text { Morgan Hill } \\
\text { Loma Prieta } \\
\text { Morgan Hill } \\
\text { Mount Lewis } \\
\text { San Fernando } \\
\text { Whittier } \\
\text { Whittier } \\
\text { San Fernando } \\
\text { Whittier }\end{array}$ & $\begin{array}{l}2.80 \\
1.40 \\
1.80 \\
1.90 \\
1.40 \\
0.90 \\
1.00 \\
\text { SW } \\
2.15 \\
1.43 \\
1.90 \\
1.10 \\
\text { NA } \\
1.46 \\
1.40 \\
3.11 \\
1.39 \\
2.27 \\
2.27 \\
2.24 \\
1.94 \\
1.84 \\
2.60 \\
2.15 \\
0.28 \\
0.27 \\
0.85 \\
0.85 \\
0.83 \\
1.01 \\
0.91 \\
0.91 \\
1.20 \\
1.90 \\
\text { NA } \\
0.79 \\
1.40\end{array}$ & $\begin{array}{l}2.80 \\
1.30 \\
1.60 \\
2.40 \\
1.60 \\
1.20 \\
1.00 \\
1.33 \\
2.22 \\
1.60 \\
2.20 \\
1.80 \\
2.28 \\
1.61 \\
1.30 \\
3.19 \\
1.28 \\
2.09 \\
2.13 \\
1.98 \\
2.14 \\
2.17 \\
2.62 \\
2.21 \\
0.30 \\
0.29 \\
1.10 \\
1.02 \\
0.83 \\
S W \\
S W \\
S W \\
1.40 \\
2.30 \\
2.44 \\
0.88 \\
1.20\end{array}$ \\
\hline
\end{tabular}

Note: *Denotes buildings with $\ddot{u}_{g 0} \geq 0.15 g$; NA indicates data not available; $S W$ implies shear walls form the lateral-load resisting system; number followed by " $C$ " or " $N$ " indicates the station number and by "ATC" indicates the building number in ATC3-06 report.

steel MRF buildings, respectively, with one exception: in ATC3-06 recommendations $C_{t}=0.025$ for RC MRF buildings.

Eq. (1), which first appeared in the ATC3-06 report, was derived using Rayleigh's method (Chopra 1995) with the following assumptions: (1) Equivalent static lateral forces are distributed linearly over the height of the building; (2) seismic base shear is proportional to $1 / T^{2 / 3}$; and (3) deflections of the building are controlled by drift limitations. Although the first two assumptions are evident, the third assumption implies that the heightwise distribution of stiffness is such that the interstory drift under linearly distributed forces is uniform over the height of the building. Numerical values of $C_{t}=0.035$ and 0.025 for steel and RC MRF buildings were established in the ATC3-06 report based on measured periods of buildings from their motions recorded during the 1971 San Fernando earthquake. The commentary to SEAOC-88 (SEAOC 1988) states that " . . data upon which the ATC3-06 values were based were re-examined for concrete frames and the 0.030 value judged to be more appropriate." This judgmental change was adopted by other codes.

The NEHRP-94 provisions also recommend an alternative formula for RC and steel MRF buildings

$$
T=0.1 N
$$

where $N=$ number of stories. The simple formula is restricted to buildings not exceeding 12 stories in height and having a minimum story height of $10 \mathrm{ft}$. This formula also was specified in earlier versions of other seismic codes before it was replaced by (1).

The UBC-97 (UBC 1997) and SEAOC-96 codes specify that the design base shear should be calculated from

$$
V=C W
$$

where $W=$ total seismic dead load; and $C=$ seismic coefficient defined as

$$
C=\frac{C_{v}}{R} \frac{I}{T} ; \quad 0.11 C_{a} I \leq C \leq \frac{2.5 C_{a}}{R} I
$$

and for seismic zone 4

$$
C \geq \frac{0.8 Z N_{v} I}{R}
$$

in which coefficients $C_{v}$ and $C_{a}$ depend on the near-source factors $N_{v}$ and $N_{a}$, respectively, along with the soil profile and the seismic zone factor $Z ; I$ is the important factor; and the $R$ is the numerical coefficient representative of the inherent overstrength and global ductility capacity of the lateral-load resisting system. The upper limit of $2.5 C_{a} I \div R$ on $C$ applies to very short-period buildings, whereas the lower limit of $0.11 C_{a} I$ (or $0.8 Z N_{v} I \div R$ for seismic zone 4) applies to very long-period buildings. These limits imply that $C$ becomes independent of the period for very short or very tall buildings. 
TABLE 2. Period Data for Steel MRF Buildings

\begin{tabular}{|c|c|c|c|c|c|c|c|}
\hline \multirow[b]{2}{*}{$\begin{array}{l}\text { No. } \\
(1)\end{array}$} & \multirow[b]{2}{*}{$\begin{array}{l}\text { Location } \\
\text { (2) }\end{array}$} & \multirow[b]{2}{*}{$\begin{array}{c}\text { ID number } \\
(3)\end{array}$} & \multirow[b]{2}{*}{$\begin{array}{c}\text { No. of stories } \\
\text { (4) }\end{array}$} & \multirow[b]{2}{*}{$\begin{array}{l}\text { Height (ft) } \\
(5)\end{array}$} & \multirow[b]{2}{*}{$\begin{array}{c}\text { Earthquake name } \\
(6)\end{array}$} & \multicolumn{2}{|c|}{ Period $T$ (s) } \\
\hline & & & & & & $\begin{array}{l}\text { Longitudinal } \\
\text { (7) }\end{array}$ & $\begin{array}{c}\text { Transverse } \\
\text { (8) }\end{array}$ \\
\hline $1^{*}$ & Alhambra & $\mathrm{U} 482$ & 13 & 198.0 & Northridge & 2.15 & 2.20 \\
\hline $2 *$ & Burbank & $\mathrm{C} 24370$ & 6 & 82.5 & Northridge & 1.36 & 1.38 \\
\hline $3^{*}$ & Burbank & $\mathrm{C} 24370$ & 6 & 82.5 & Whittier & 1.32 & 1.30 \\
\hline 4 & Long Beach & $\mathrm{C} 14323$ & 7 & 91.0 & Whittier & 1.19 & 1.50 \\
\hline 5 & Los Angeles & ATC 1 & 19 & 208.5 & San Fernando & 3.00 & 3.21 \\
\hline 6 & Los Angeles & ATC 10 & 39 & 494.0 & San Fernando & 5.00 & 4.76 \\
\hline 7 & Los Angeles & ATC _ 11 & 15 & 202.0 & San Fernando & 2.91 & 2.79 \\
\hline 8 & Los Angeles & ATC_ 12 & 31 & 336.5 & San Fernando & 3.26 & 3.00 \\
\hline 9 & Los Angeles & $\mathrm{ATC}_{-} 13$ & NA & 102.0 & San Fernando & 1.71 & 1.62 \\
\hline 10 & Los Angeles & ATC_14 & NA & 158.5 & San Fernando & 2.76 & 2.38 \\
\hline 11 & Los Angeles & ATC 15 & 41 & 599.0 & San Fernando & 6.00 & 5.50 \\
\hline 12 & Los Angeles & ATC_ 17 & NA & 81.5 & San Fernando & 1.85 & 1.71 \\
\hline 13 & Los Angeles & ATC_3 & NA & 120.0 & San Fernando & 2.41 & 2.23 \\
\hline 14 & Los Angeles & ATC_4 & 27 & 368.5 & San Fernando & 4.38 & 4.18 \\
\hline 15 & Los Angeles & ATC. 5 & 19 & 267.0 & San Fernando & 3.97 & 3.50 \\
\hline 16 & Los Angeles & ATC_6 & 17 & 207.0 & San Fernando & 3.00 & 2.28 \\
\hline 17 & Los Angeles & ATC _ 7 & NA & 250.0 & San Fernando & 4.03 & 3.88 \\
\hline 18 & Los Angeles & ATC_8 & 32 & 428.5 & San Fernando & 5.00 & 5.40 \\
\hline 19 & Los Angeles & ATC_9 & NA & 208.5 & San Fernando & 3.20 & 3.20 \\
\hline $20^{*}$ & Los Angeles & C24643 & 19 & 270.0 & Northridge & 3.89 & BF \\
\hline 21 & Los Angeles & N151-3 & 15 & 202.0 & San Fernando & 2.84 & 2.77 \\
\hline 22 & Los Angeles & N157.9 & 39 & 459.0 & San Fernando & 4.65 & NA \\
\hline 23 & Los Angeles & N163-5 & 41 & 599.0 & San Fernando & 6.06 & 5.40 \\
\hline $24^{*}$ & Los Angeles & N172-4 & 31 & 336.5 & San Fernando & 3.38 & 2.90 \\
\hline $25^{*}$ & Los Angeles & N172-4 & 31 & 336.5 & San Fernando & 3.42 & 2.94 \\
\hline 26 & Los Angeles & N184-6 & 27 & 398.0 & San Fernando & 4.27 & 4.26 \\
\hline 27 & Los Angeles & N184-6 & 27 & 398.0 & San Fernando & 4.37 & 4.24 \\
\hline $28 *$ & Los Angeles & N187-9 & 19 & 270.0 & San Fernando & 3.43 & 3.41 \\
\hline 29 & Los Angeles & N428-30 & 32 & 443.5 & San Fernando & 4.86 & 5.50 \\
\hline 30 & Los Angeles & $\mathrm{N} 440-2$ & 17 & 207.0 & San Fernando & 2.85 & 3.43 \\
\hline $31 *$ & Los Angeles & N461-3 & 19 & 231.7 & San Fernando & 3.27 & 3.34 \\
\hline $32 *$ & Los Angeles & N461-3 & 19 & 231.7 & San Fernando & 3.02 & 3.30 \\
\hline $33 *$ & Los Angeles & N461-3 & 19 & 231.7 & San Fernando & 3.28 & 3.34 \\
\hline $34 *$ & Los Angeles & U5208 & 6 & 104.0 & Northridge & 0.94 & 0.96 \\
\hline $35^{*}$ & Los Angeles & U5233 & 32 & 430.0 & Northridge & 3.43 & 4.36 \\
\hline $36 *$ & Norwalk & U5239 & 7 & 96.0 & Whittier & 1.54 & 1.54 \\
\hline $37 *$ & Norwalk & U5239 & 7 & 98.0 & Whittier & 1.30 & 1.22 \\
\hline $38 *$ & Palm Springs & C12299 & 4 & 51.5 & Palm Springs & 0.71 & 0.63 \\
\hline 39 & Pasadena & ATC_2 & 9 & 128.5 & San Fernando & 1.29 & 1.44 \\
\hline $40^{*}$ & Pasadena & C24541 & 6 & 92.3 & Northridge & 2.19 & 1.79 \\
\hline 41 & Pasadena & N267-8 & 9 & 130.0 & Lytle Creek & 1.02 & 1.13 \\
\hline 42 & Pasadena & N267-8 & 9 & 130.0 & San Fernando & 1.26 & 1.42 \\
\hline 43 & Richmond & C58506 & 3 & 45.0 & Loma Prieta & 0.63 & 0.74 \\
\hline 44 & Richmond & C58506 & 3 & 45,0 & Loma Prieta & 0.60 & 0.76 \\
\hline 45 & San Bernandino & $\mathrm{C} 23516$ & 3 & 41.3 & Whittier & 0.50 & 0.46 \\
\hline $46^{*}$ & San Francisco & C58532 & 47 & 564.0 & Loma Prieta & 6.25 & $\mathrm{EBF}$ \\
\hline $47^{*}$ & San Francisco & C58532 & 47 & 564.0 & Loma Prieta & 6.50 & EBF \\
\hline 48 & San Francisco & NA & 60 & 843.2 & Loma Prieta & 3.57 & 3.57 \\
\hline $49 *$ & San Jose & C57357 & 13 & 186.6 & Loma Prieta & 2.22 & 2.22 \\
\hline $50^{*}$ & San Jose & C57357 & 13 & 186.6 & Loma Prieta & 2.23 & 2.23 \\
\hline 51 & San Jose & C57357 & 13 & 186.6 & Morgan Hill & 2.05 & 2.16 \\
\hline 52 & San Jose & C57562 & 3 & 49.5 & Loma Prieta & 0.67 & 0.69 \\
\hline 53 & San Jose & C57562 & 3 & 49.5 & Loma Prieta & 0.69 & 0.69 \\
\hline
\end{tabular}

Note: "Denotes building with $\ddot{u}_{z 0} \geq 0.15 \mathrm{~g}$. NA indicates data not available; BF implies braced frame and EBF means eccentric braced frame form the lateral-load resisting system; number followed by " $\mathrm{C}$," " $\mathrm{N}$," or " $\mathrm{U}$ " indicates the station number and by "ATC" indicates the building number in ATC3-06 report.

The upper limit existed, although in slightly different form, in previous versions of UBC and SEAOC blue book; the lower limit, however, appeared only recently in UBC-97 and SEAOC-96.

The fundamental period $T$, calculated using the empirical formula in (1), should be smaller than the "true" period to obtain a conservative estimate for the base shear. Therefore, code formulas are calibrated intentionally to underestimate the period by approximately $10-20 \%$ at first yield of the building (ATC 1978; SEAOC 1988).

The codes permit calculation of the period by a rational analysis, such as Rayleigh's method, but specify that the resulting value should not be longer than that estimated from the empirical formula [see (1)] by a certain factor. The following are factors specified in various U.S. codes: 1.2 in ATC3. 06; 1.3 for high-seismic region (zone 4) and 1.4 for other regions (zones 3, 2, and 1) in UBC-97; and a range of values with 1.2 for regions of high seismicity to 1.7 for regions of very low seismicity in NEHRP-94. The restriction in SEAOC88 that the base shear calculated using the rational period shall not be less than $80 \%$ of the value obtained by using the empirical period corresponds to a factor of 1.4 (Cole et al. 1992). These restrictions are imposed in order to safeguard against unreasonable assumptions in the rational analysis, which may lead to unreasonably long periods and hence unconservative values of base shear. 


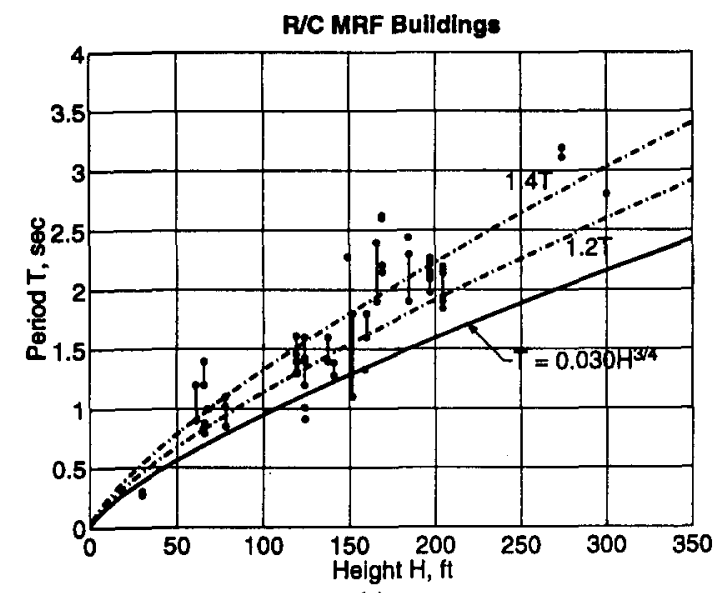

(a)

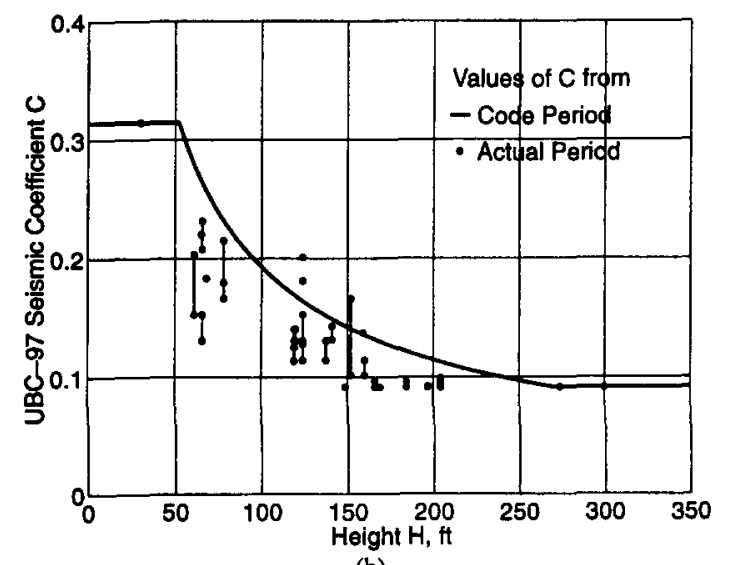

(b)

FIG. 1. Comparison of: (a) Measured and Code Periods; (b) UBC-97 Selsmic Coefficients from Measured and Code Periods for RC MRF Bulldings

\section{EVALUATION OF CODE FORMULAS}

For buildings listed in Tables 1 and 2, the fundamental period identified from their motions recorded during earthquakes (subsequently denoted as measured period) is compared with the value given by the empirical code formula [Figs. 1-4, part (a)]; the measured periods in two orthogonal lateral directions are shown by solid circles connected by a vertical line, whereas code periods are shown by a single solid curve because the code formula gives the same period in the two directions if the lateral resisting systems are of the same type. Also included are curves for $1.2 T$ and $1.4 T$ representing the limits imposed by codes on the rational value of the period for use in high-seismic regions like California. Also compared are the two values of the seismic coefficient for each building calculated according to (4) and (5) with $I=1$ for standard occupancy structures; $R=3.5$ for ordinary concrete MRFs or $R=4.5$ for ordinary steel MRFs; and $C_{v}=0.64$ and $C_{a}=0.44$ for seismic zone 4 with $Z=0.4$, soil profile type $S_{D}$, i.e., stiff profile with average shear-wave velocity between 180 and 360 $\mathrm{m} / \mathrm{s}$ and $N_{v}=N_{a}=1$. The seismic coefficients corresponding to the measured periods in the two orthogonal directions are shown by solid circles connected by a vertical line, whereas the value based on the code period is shown by a solid curve.

\section{RC MRF Buildings}

The data shown in Fig. 1 for all RC MRF buildings (Table 1) permit the following observations. The code formula is close to the lower bound of measured periods for buildings up to $160 \mathrm{ft}$ high, but leads to periods significantly shorter than

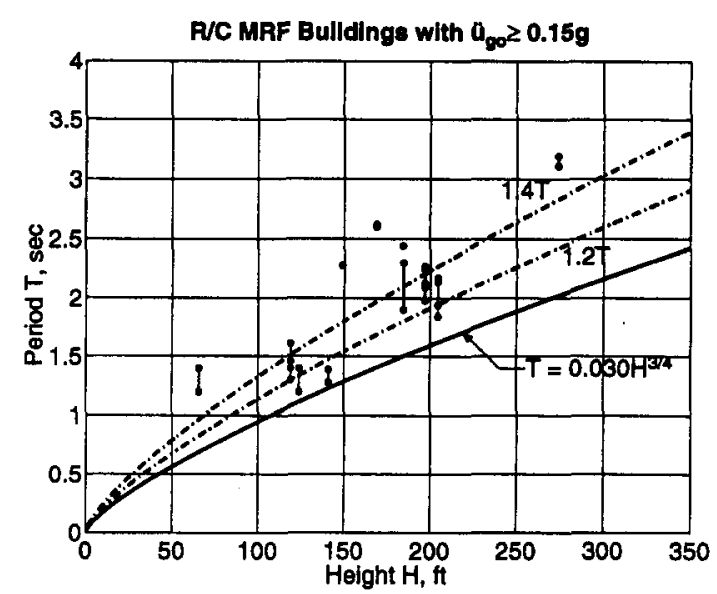

(a)

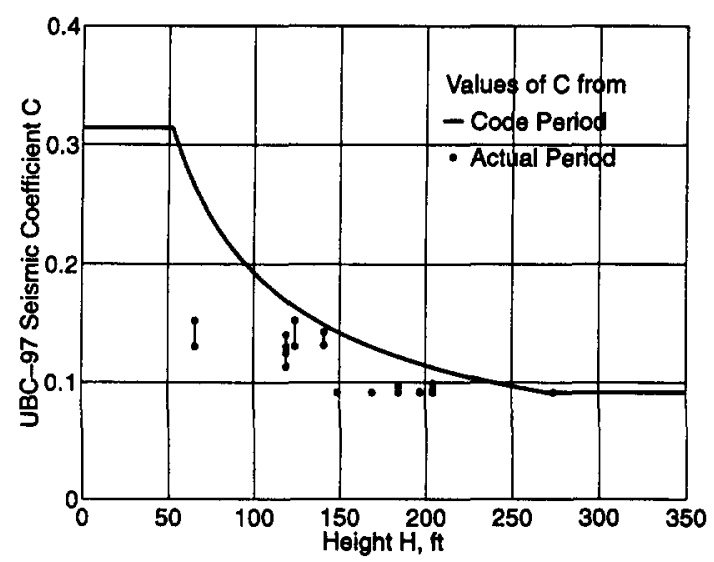

(b)

FIG. 2. Comparison of: (a) Measured and Code Periods; (b) UBC-97 Seismic Coefficients from Measured and Code Periods for RC MRF Buildings with $\ddot{u}_{g 0} \geq 0.15 \mathrm{~g}$.

the measured periods for buildings in the height range of $160-225 \mathrm{ft}$. For such buildings, the lower bound tends to be about 1.2 times the code period. Although data for RC MRF buildings taller than $225 \mathrm{ft}$ is limited, it appears that the measured period of such buildings is much longer than the code value. The measured periods of most RC MRF buildings fall between the curves for $1.2 T$ and $1.4 T$, indicating that the code limits on the period calculated from rational analysis may be reasonable for high-seismic regions like California; improved limits are proposed later. Data on measured periods of buildings in regions of low seismicity are needed to evaluate the much higher values of $1.7 T$ permitted in NEHRP-94 to reflect the expectation that these buildings are likely to be more flexible (Commentary for NEHRP-94). The seismic coefficient calculated from the code period is conservative for most buildings because the code period is shorter than the measured period. For very short ( $H$ less than approximately $50 \mathrm{ft}$ ) or very tall ( $H$ more than approximately $250 \mathrm{ft}$ ) buildings, measured and code periods lead to the same seismic coefficient as $C$ becomes independent of the period.

Because for design application it is most useful to examine the periods of buildings that have been shaken strongly but did not reach their yield limit, the data for buildings subjected to $\ddot{u}_{g 0} \geq 0.15 g$ (denoted with an asterisk in Table 1) are separated in Fig. 2. These data permit the following observations. For buildings of similar height, the fundamental period of strongly shaken buildings is longer compared with less strongly shaken buildings because of increased cracking of RC that results in reduced stiffness. As a result the measured periods are in all cases longer than their code values, in most 


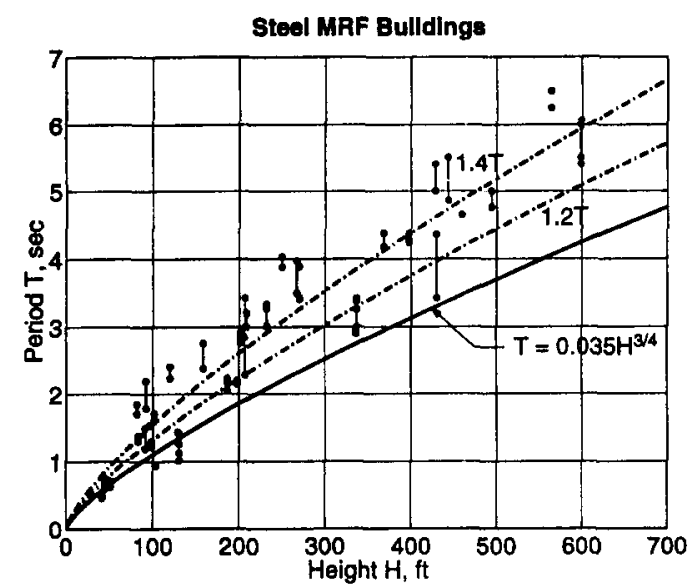

(a)

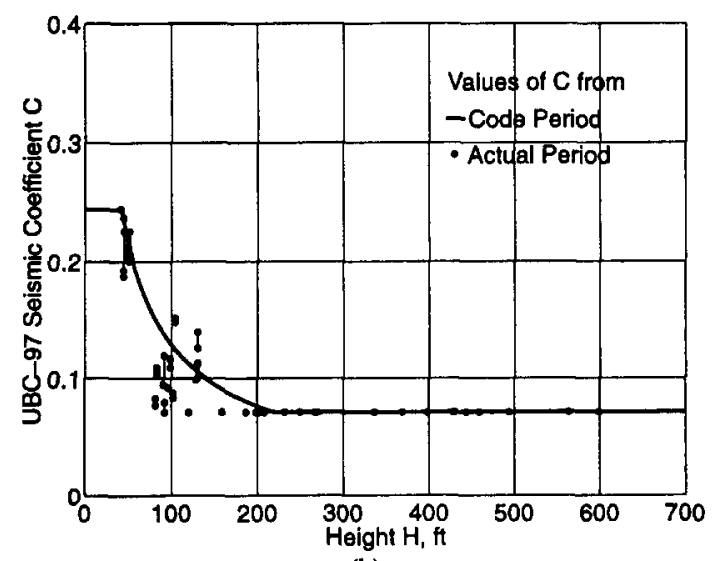

(b)

FIG. 3. Comparlson of: (a) Measured and Code Periods; (b) UBC-97 Selsmic Coefficients from Measured and Code Periods for Steel MRF Bulldings

cases much longer. The lower bound of measured periods of strongly shaken buildings is close to 1.2 times the code period. Thus the coefficient $C_{t}=0.030$ in current codes seems to be too small and a value like 0.035 , as will be seen later from the results of regression analysis, may be more appropriate. Just as observed from the data for all buildings, the seismic coefficient value calculated using the code period is conservative for most strongly shaken buildings and the conservatism is larger; exception occurs for very short or very tall buildings for which the seismic coefficient is independent of the period.

\section{Steel MRF Buildings}

The data presented in Fig. 3 for all steel MRF buildings (Table 2) permit the following observations. The code formula leads to periods that are generally shorter than measured periods, with the margin between the two being much larger than for RC MRF buildings [Fig. 1(a)]. The code formula gives periods close to the lower bound of measured periods for buildings up to about $120 \mathrm{ft}$ high but $20-30 \%$ shorter for buildings taller than $120 \mathrm{ft}$; this conclusion is based on a larger data set compared with the meager data for RC MRF buildings. For many buildings the measured periods exceed $1.4 T$, indicating that the code limits on the period calculated from rational analysis are too restrictive. The seismic coefficient value calculated from the code period is conservative for most buildings and the degree of conservatism is larger compared with RC buildings; as noted previously for RC buildings, exception occurs for very short or very tall buildings for which the seismic coefficient is independent of the period.

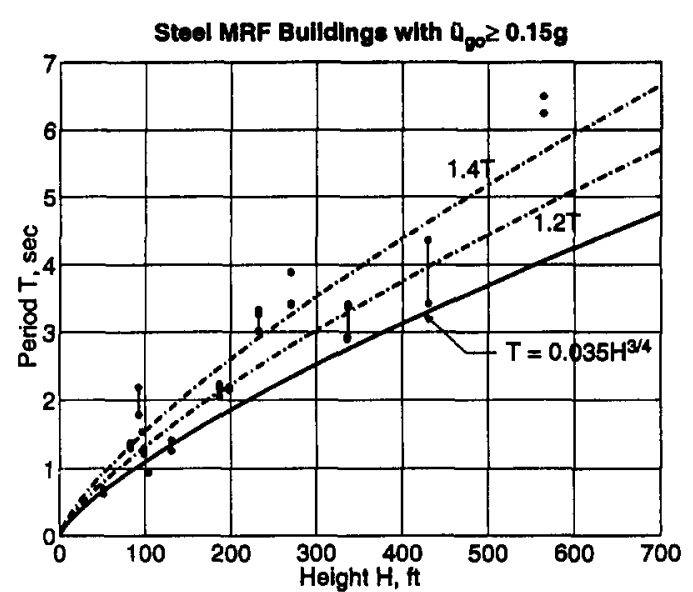

(a)

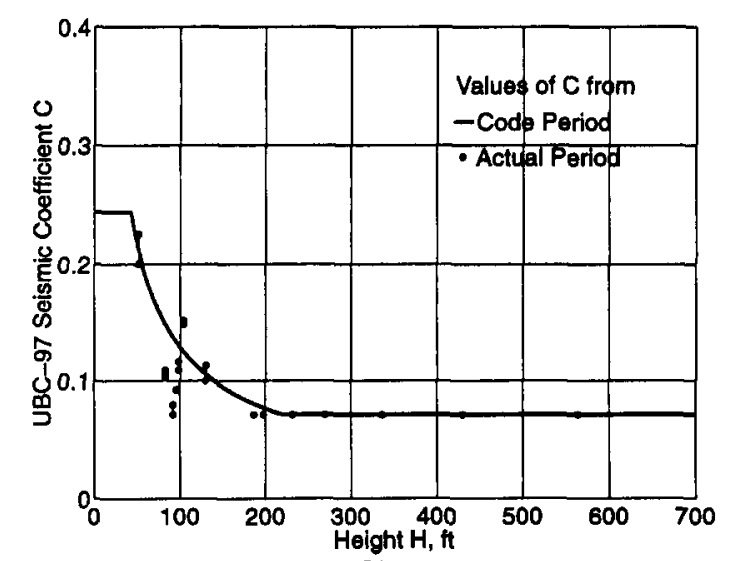

(b)

FIG. 4. Comparison of: (a) Measured and Code Periods; (b) UBC-97 Selsmic Coefficlents from Measured and Code Periods for Steel MRF Bulldings with $\ddot{u}_{g 0} \geq 0.15 g$

The data for steel MRF buildings subjected to ground acceleration of $0.15 \mathrm{~g}$ or more (denoted with an asterisk in Table 2) are separated in Fig. 4. When comparing these data with Fig. 3, it can be observed that the intensity of ground shaking has little influence on the measured period. The period elongates slightly because of stronger shaking but less than for RC buildings, which exhibit significantly longer periods because of increased cracking. Thus period data from all levels of shaking of buildings, remaining essential elastic may be used to develop improved formulas for fundamental periods of steel MRF buildings.

\section{THEORETICAL FORMULAS}

Although the results presented in the preceding section indicate that the code formulas provide periods that are, in general, shorter than the measured periods, leading to conservative estimates of design forces, these formulas may be improved to provide better correlation with the measured periods. The relation between the period and building height in the improved formulas should be consistent with theoretical formulas presented next.

With the use of Rayleigh's method, the following relationships for fundamental period of multistory building frames with equal floor masses and story heights have been determined (Housner and Brady 1963; Goel and Chopra 1997, Appendix E):

$$
T=C_{1} \sqrt{H} \text { or } C_{2} H
$$

The exponent of $H$ and the numerical values of $C_{1}$ and $C_{2}$ 
depend on the stiffness properties, including their heightwise variation.

Another formula for the fundamental period has been derived by Rayleigh's method under the following assumptions: (1) Lateral forces are distributed linearly (triangular variation of forces) over the building height; (2) base shear is proportional to $1 / T^{\gamma}$; (3) weight of the building is distributed uniformally over its height; and (4) deflected shape of the building, under application of the lateral forces, is linear over its height, which implies that the interstory drift is the same for all stories. The result of this derivation (Goel and Chopra 1997, Appendix $D$ ) is

$$
T=C_{3} H^{1 /(2-\gamma)}
$$

If the base shear is proportional to $1 / T^{2 / 3}$, as in U.S. codes [see (4)], $\gamma=2 / 3$ and (7) gives

$$
T=C_{4} H^{3 / 4}
$$

which is in the ATC3-06 report and appears in current U.S. codes.

The formulas presented in (6) $-(8)$ are of the form

$$
T=\alpha H^{\beta}
$$

in which constants $\alpha$ and $\beta$ depend on building properties, with $\beta$ bounded between one-half and one. This form is adopted in the present paper and constants $\alpha$ and $\beta$ are determined by regression analysis of the measured period data.

\section{REGRESSION ANALYSIS METHOD} (9) as

For the purpose of regression analysis, it is useful to recast

$$
y=a+\beta x
$$

in which $y=\log (T), a=\log (\alpha)$, and $x=\log (H)$. The intercept $a$ at $x=0$ and slope $\beta$ of the straight line of $(10)$ were determined by minimizing the squared error between the measured and computed periods, and then $\alpha$ was back-calculated from the relationship $a=\log (\alpha)$. The standard error of estimate is

$$
s_{e}=\sqrt{\frac{\sum_{i=1}^{n}\left[y_{i}-\left(a+\beta x_{i}\right)\right]^{2}}{(n-2)}}
$$

where $y_{i}=\log \left(T_{i}\right)=$ observed value (with $T_{i}=$ measured period); $\left(a+\beta x_{i}\right)=\left[\log (\alpha)+\beta \log \left(H_{i}\right)\right]=$ computed value of the $i$ th data; and $n=$ total number of data points. The $s_{e}$ represents scatter in the data and approaches, for large $n$, the standard deviation of the measured periods from the best-fit equation.

This procedure leads to values of $\alpha_{R}$ and $\beta$ for (9) to represent the best-fit, in the least-squared sense, to the measured period data. However, for code applications the formula should provide lower values of the period, and this was obtained by lowering the best-fit line [see (10)] by $s_{e}$ without changing its slope. Thus $\alpha_{L}$, the lower value of $\alpha$, is computed from

$$
\log \left(\alpha_{L}\right)=\log \left(\alpha_{R}\right)-s_{e}
$$

Because $s_{e}$ approaches the standard deviation for large number of samples and $y$ is lognormal, $\alpha_{L}$ is the mean minus one standard deviation or 15.9 percentile value, implying that $15.9 \%$ of the measured periods would fall below the curve corresponding to $\alpha_{L}$ (subsequently referred to as the best-fit $1 \sigma$ curve). If desired, $\alpha_{L}$ corresponding to other nonexceedance probabilities may be selected. Additional details of the regression analysis method and the procedure to estimate $\alpha_{L}$ are available elsewhere (Goel and Chopra 1997. Appendix F).
TABLE 3. Results from Regression Analysis: RC MRF Bulldings

\begin{tabular}{c|l|c|c}
\hline \hline \multirow{2}{*}{$\begin{array}{c}\text { Regression analysis type } \\
\text { (1) }\end{array}$} & \multicolumn{3}{|c}{ Period Formula } \\
\cline { 2 - 4 } & \multicolumn{1}{|c|}{$(2)$} & \multicolumn{1}{|c}{$(3)$} & $(4)$ \\
\hline Unconstrained & $T_{R}=0.017 H^{0.92}$ & $T_{L}=0.014 H^{0.92}$ & 0.209 \\
Constrained with $\beta=0.90$ & $T_{R}=0.108 H^{0.90}$ & $T_{L}=0.015 H^{0.90}$ & 0.209 \\
Constrained with $\beta=0.75$ & $T_{R}=0038 H^{0.75}$ & $T_{L}=0.030 H^{0.73}$ & 0.229 \\
Constrained with $\beta=1$ & $T_{R}=0.011 H$ & $T_{L}=0.009 H$ & 0.214 \\
\hline \hline
\end{tabular}

TABLE 4. Results from Regression Analysis: Steel MRF Bulldings

\begin{tabular}{l|c|c|c}
\hline \hline \multirow{4}{*}{$\begin{array}{c}\text { Regression analysis type } \\
\text { (1) }\end{array}$} & \multicolumn{3}{|c}{ Period Formula } \\
\cline { 2 - 4 } & \multicolumn{1}{|c|}{ Best-fit } & $\begin{array}{c}\text { Best-fit }-1 \sigma \\
(3)\end{array}$ & $\begin{array}{c}S_{Q} \\
(4)\end{array}$ \\
\hline Unconstrained & $T_{R}=0.035 H^{0.805}$ & $T_{L}=0.027 H^{0.805}$ & 0.233 \\
Constrained with $\beta=0.80$ & $T_{R}=0.035 H^{0.80}$ & $T_{L}=0.028 H^{0.80}$ & 0.233 \\
Constrained with $\beta=0.75$ & $T_{R}=0046 H^{0.75}$ & $T_{L}=0.036 H^{0.75}$ & 0.237 \\
Constrained with $\beta=1.0$ & $T_{R}=0.013 H$ & $T_{L}=0.009 H$ & 0.277 \\
\hline \hline
\end{tabular}

As mentioned previously, codes also specify an upper limit on the period calculated by rational analysis. This limit is established in this investigation by raising the best-fit line [see (10)] by $s_{e}$ without changing its slope. Thus $\alpha_{U}$, the value of $\alpha$ corresponding to the upper limit, is computed from

$$
\log \left(\alpha_{U}\right)=\log \left(\alpha_{R}\right)+s_{e}
$$

Eq. (9) with $\alpha_{U}$ and $\beta$ represents the best-fit $+1 \sigma$ curve, which will be exceeded by $15.9 \%$ of the measured periods.

\section{RESULTS OF REGRESSION ANALYSIS}

For each of the two categories of MRF buildings - RC and steel-results are presented for the following regression analyses:

1. Unconstrained regression analysis to determine $\alpha$ and $\beta$

2. Constrained regression analysis to determine $\alpha$ with the value of $\beta$ from unconstrained regression analysis rounded off to the nearest 0.05 , e.g., $\beta=0.92$ is rounded off to 0.90 and $\beta=0.63$ to 0.65 .

3. Constrained regression analysis to determine $\alpha$ with $\beta$ fixed at 0.75 , the value in some current building codes [see (1)]

4. Constrained regression analysis to determine $\alpha$ with $\beta$ fixed at 1.0 , the value that corresponds to the alternative formula specified in NEHRP-94 [see (2)]

These regression analyses, implemented using the data from all buildings (Tables 1 and 2), lead to the formulas in Table 3 for RC MRF buildings and in Table 4 for steel MRF buildings. To permit visual inspection, the formulas obtained from the second, third, and fourth regression analyses are presented in Figs. 5 and 6 together with the measured period data. To preserve clarity in the plots, the formulas from the first regression, which are close to those from the second regression, are not included in these figures. The best-fit curves are labeled as $T_{R}$ and the best-fit - $1 \sigma$ curves as $T_{L}$.

\section{RC MRF Buildings}

Fig. 5 gives an impression of the scatter in the data of the measured periods relative to curves from regression analyses. As expected the data fall above and below the curve, more or less evenly, and most of the data are above the best-fit $-1 \sigma$ curve. Observe that, as expected, constrained regression generally implies a larger standard error of estimate $s_{e}$ (Table 3), 


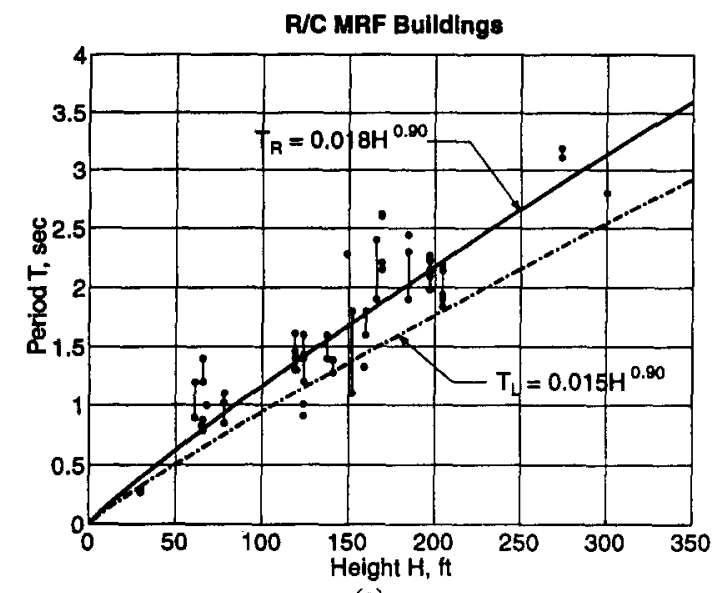

(a)

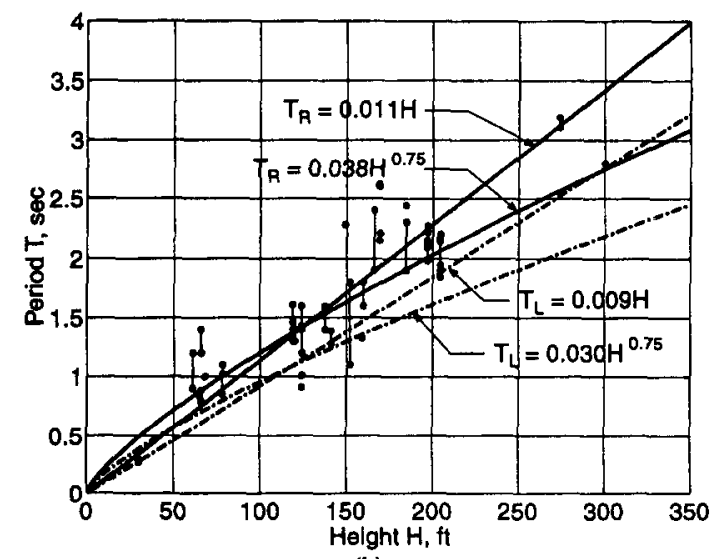

(b)

FIG. 5. Regression Analysis for RC MRF Buildings: (a) $\beta=$ $0.90 ;(b) \beta=0.75$ and 1.0

indicating greater scatter of the data about the best-fit curve; $s_{e}$ increases as the value of $\beta$ deviates increasingly from its unconstrained regression value. However, $s_{e}$ is insensitive to $\beta$ in the immediate vicinity of its unconstrained regression value, as evident from nearly identical values (up to three digits after the decimal point) of $s_{e}$ from the first two regression analyses (Table 3 ). The value of $s_{e}$ is significantly larger if $\beta=0.75$ or 1.0 , demonstrating that the period formula with either of these $\beta$ values, as in present U.S. codes, is less accurate. Thus the best choice is $\beta=0.90$ with the associated $\alpha$ $=0.015$.

The values of $\alpha$ and $\beta$, determined from all available data, should be modified to recognize that the period of an RC building lengthens at levels of motion large enough to cause cracking of concrete. The data from buildings experiencing $\ddot{\mathrm{u}}_{\mathrm{g} 0} \geq 0.15 \mathrm{~g}$ are too few (Fig. 2) to permit a reliable value of $\beta$ from unconstrained regression analysis. Therefore, constrained regression analysis of these data with $\beta=0.90$, determined from the full set of data, was conducted to obtain $\alpha_{L}$ $=0.016$ and $\alpha_{U}=0.023$ leading to

$$
T_{L}=0.016 H^{0.90}
$$

and

$$
T_{U}=0.023 H^{0.90}
$$

Eqs. (14) and (15) are plotted in Fig. 7 together with the measured period data. As expected, very few data fall above the curve for $T_{U}$ or below the curve for $T_{L}$. This indicates that (14) is suitable for estimating, conservatively, the fundamental period and (15) for limiting the period computed from rational analysis. This period should not be longer than $1.4 T_{L}$; the fac- tor 1.4 is determined as the ratio $0.023: 0.016$, rounded-off to one digit after the decimal point.

\section{Steel MRF Buildings}

Fig. 6 gives an impression of the scatter in the measured period data relative to the best-fit curve. As expected the data fall above and below the curve, more or less evenly, and most of the data are above the best-fit - 10 curve. Observe that values of $s_{e}$ are almost identical for unconstrained regression and constrained regression with rounded-off value of $\beta$ because this value is close to the regressed value (Table 4); however, $s_{e}$ increases as the value of $\beta$ deviates increasingly from

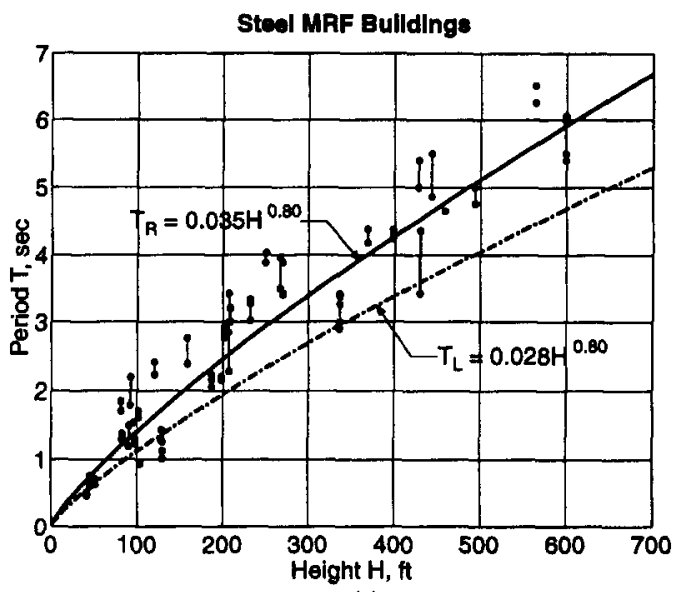

(a)

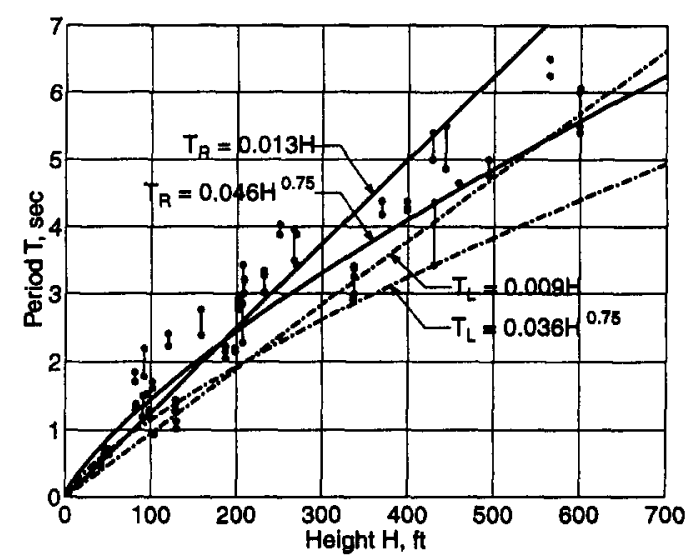

(b)

FIG. 6. Regression Analysis for Steel MRF Bulldings: (a) $\beta=$ $0.80 ;(b) \beta=0.75$ and 1.0

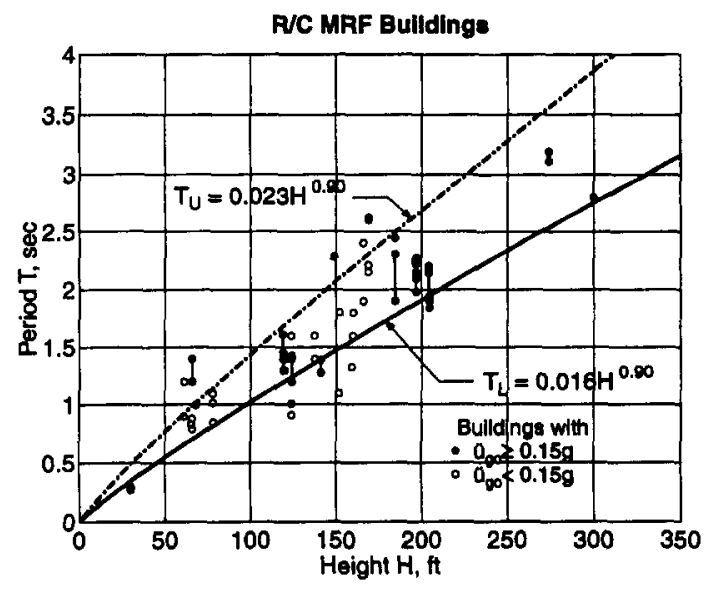

FIG. 7. Recommended Period Formula and Upper Limit for Fundamental Period of RC MRF Bulldings 


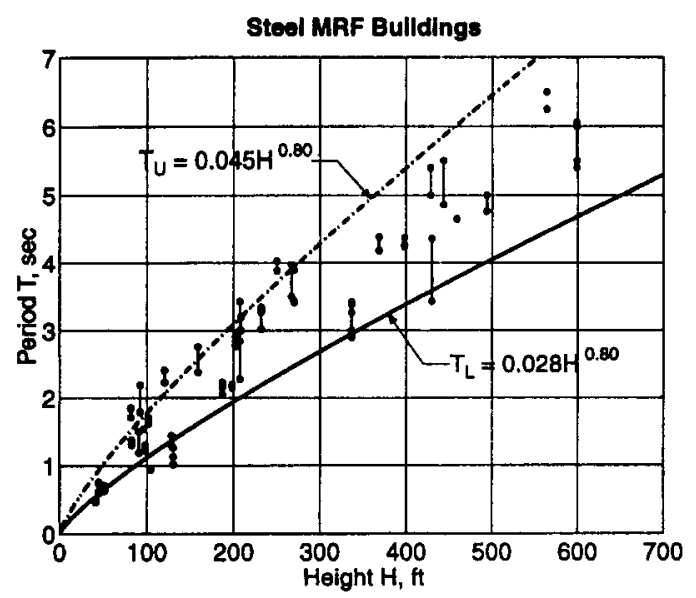

FIG. 8. Recommended Period Formula and Upper Limit for Fundamental Period of Steel MRF Buildings

its unconstrained regression value. It is larger if $\beta=0.75$ or 1.0 , demonstrating that the period formula with either of these $\beta$ values, as in present U.S. codes, is less accurate. Thus the best choice is $\beta=0.80$ with the associated $\alpha_{L}=0.028$ and $\alpha_{U}$ $=0.045$ leading to

$$
T_{L}=0.028 H^{0.80}
$$

and

$$
T_{U}=0.045 H^{0.80}
$$

Eqs. (16) and (17) are plotted in Fig. 8 together with the measured period data. As observed earlier for RC buildings, (16) is suitable for estimating, conservatively, the fundamental period and (17) for limiting the period from rational analysis. The period from rational analysis should not be longer than $1.6 T_{L}$; the factor 1.6 is determined as the ratio $0.045: 0.028$, rounded-off to one digit after the decimal point. The period formula [see (16)] and the factor 1.6, determined from all available data, also apply to strongly shaken buildings because, as observed earlier, the intensity of shaking has little influence on the period of steel MRF buildings, so long as there is no significant yielding of the structure.

\section{CONCLUSIONS AND RECOMMENDATIONS}

Based on analysis of the available data for the fundamental vibration period of 27 RC MRF buildings and 42 steel MRF buildings, measured from their motions recorded during earthquakes, (14) and (16) are recommended for estimating, conservatively, the period of RC and steel buildings, respectively. These formulas provide the best fit of (9) to the available data; the fit is better than possible with $\beta=0.75$ or 1.0 in current U.S. codes. Furthermore, the period from rational analysis should not be allowed to exceed the value from the recommended equations by a factor larger than 1.4 for RC MRF buildings or 1.6 for steel MRF buildings. Because these recommendations are developed based on data from buildings in California, they should be applied with discretion to buildings in less-seismic regions of the United States or other parts of the world where building design practice is significantly different than in California.

Regression analyses that led to the recommended formulas should be repeated periodically on larger data sets. The database can be expanded by including buildings, other than those in Tables 1 and 2, whose motions recorded during past earthquakes have, so far, not been analyzed. Period data should also be developed for additional buildings when records of their motions during future earthquakes become available.

\section{ACKNOWLEDGMENTS}

This research investigation is supported by the National Science Foundation under Grant CMS-9416265. The writers are grateful for this support. The writers also acknowledge the assistance provided by Anthony Shakal, Moh Huang, Bob Darragh, Gustavo Maldonado, and Praveen Malhotra of the California Strong Motion Instrumentation Program in obtaining recorded motions and structural plans and by Professors S. T. Mau and J. L. Beck, and Dr. M. Celebi in implementing the system identification procedures.

\section{APPENDIX. REFERENCES}

Applied Technological Council. (1978). "Tentative provisions for the development of seismic regulations for buildings." Rep. No. ATC3-06, Applied Technological Council, Palo Alto, Calif.

Bertero, V. V., Bendimerad, F. M., and Shah, H. C. (1988). "Fundamental period of reinforced R/C moment-resisting frame structures." Rep. No. 87, John A. Blume Earthquake Engrg. Ctr., Stanford Univ., Stanford, Calif.

Chopra, A. K. (1995). Dynamics of structures: theory and applications to earthquake engineering. Prentice-Hall, Inc., Upper Saddle River, N.J.

Cole, E. E., Tokas, C. V., and Meehan, J. F. (1992). “Analysis of recorded building data to verify or improve 1991 Uniform Building Code (UBC) period of vibration formulas." Proc., SMIP92, Strong Motion Instrumentation Program, Division of Mines and Geology, California Department of Conservation, Sacramento, Calif.

Goel, R. K., and Chopra, A. K. (1997). "Vibration properties of buildings during earthquakes." Rep. to be Published, Earthquake Engrg. Res. Ctr., Univ. of California, Berkeley, Richmond, Calif.

Hart, G. C., and Vasudevan, R. (1975). "Earthquake design of buildings: damping." J. of Struct. Div., ASCE, 101(1), 11-30.

Housner, G. W., and Brady, A. G. (1963). "Natural periods of vibration of buildings." J. Engrg. Mech. Div., ASCE, 89(4), 31-65.

NEHRP recommended provisions for the development of seismic regulations for new buildings. (1994). Building Seismic Safety Council, Washington, D.C.

Structural Engineers Association of California. (1988). Recommended lateral force requirements and tentative commentary. Seismological Committee, Structural Engineers Association of California, San Francisco, Calif.

Structural Engineers Association of California. (1996). Recommended lateral force requirements and commentary. Seismological Committee, Structural Engineers Association of California, San Francisco, Calif.

Uniform building code. (1997). International Conference of Building Officials, Whittier, Calif. 